\title{
Membranous and Cytoplasmic Expression of PD-L1 in Ovarian Cancer Cells
}

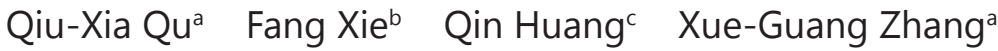 \\ aClinical Immunology Institute, the First Affiliated Hospital of Soochow University, Suzhou, bepartment \\ of Pathology, Soochow University, Suzhou, 'Department of Obstetrics and Gynecology, The First \\ Affiliated Hospital of Soochow University, Suzhou, China
}

\section{Key Words}

Tumor-associated macrophage $\bullet$ Ovarian cancer $\bullet$ PD-L1

\begin{abstract}
Background: Expression of programmed death-ligand 1 (PD-L1) on tumor cells represents a powerful immune evasion pathway, but the role of intracellular or cytoplasmic PD-L1 has not been investigated in ovarian cancer cells. Methods: Flow cytometry (FCM), Real-time PCR (qPCR), immunohistochemistry (IHC) and western blot were used to determine the expression of PD-L1 in ovarian cancer cells. The cytokines detected in the tumor or tumor associated macrophage (TAM) were used to treat cancer cells. PD-L1 blockade and silencing were used to elucidate the functional significance of cancer-related PD-L1 expression. Results: Based on the results presented, PD-L1 was found variably expressed in the cytoplasm and the cell surface of both HO8910 and SKOV3 cells. TAM or IFN- $\gamma$, TNF- $\alpha$, IL-10 and IL- 6 released from TAM stimulated the expression of PD-L1 at the surface of the cancer cells. The IHC results were consistent with the data in vitro showing infiltration of TAM correlated with membranous PD-L1. The increases of PD-L1 at the surface were not due to a shift in the proportion of surface versus intracellular protein, but the contribution of extracellular signal-regulated kinase (ERK)1/2 and phosphoinositide 3-kinase (PI3K) pathway activation. As a consequence, inducible membranous PD-L1 expression on SKOV3 inhibited $\mathrm{CD}^{+} \mathrm{T}$ cell function, and cytoplasmic PD-L1 promoted cancer cell growth. Additionally, in mouse models, both PD-L1 and PD-1 mAb resulted in tumor growth inhibition and demonstrated a potential to decrease the number of PD-1+CD8 ${ }^{+}$T cells. Conclusion: We conclude that TAM induced PD-L1 on the cancer cells represents an immune evasion mechanism. The observations confirm the therapeutic potential of PD-L1/PD-1 mAb to reactivate anti-tumor immunity in ovarian cancer.
\end{abstract}

\section{Introduction}

(C) 2017 The Author(s)

Published by S. Karger AG, Basel

Among all gynaecological cancers, ovarian carcinoma has the highest rate of mortality. At the time of diagnosis, most patients present with advanced disease. Tumour development has often been associated with either oncogene expression and amplification or inappropriate 
growth factor regulation [1]. Recent studies have provided accumulating evidence that cancers develop evasion mechanisms through aberrantly expressing proteins, to either build an inhibitory microenvironment locally or metastasize to other organs systemically [2-4]. For example, the histone acetylation and accumulation of DNA methylation in ovarian cancer cells correlates with the suppressed expression of OX-40L and 4-1BBL in chemo-resistant cancer cells and generates a suppressive microenvironment to escape immune elimination [5].

The best-characterized immunological molecules with a major impact on both cancer growth and therapy are programmed death-ligand 1 (PD-L1) and its receptor programmed death 1 (PD-1) [6-9]. By arresting the cell cycle, the PD-L1 ligation of T cells has a profound inhibitory effect on cytokine secretion, growth, and cytotoxicity [10-12]. The optimal function of tumour-reactive T cells could be attenuated through PD-1/PD-L1 signals. These observations suggest that PD-L1 expression may reflect aggressive biological potential and play an important role in tumour immune escape. For example, in ovarian cancer, the differential expression of immunological markers related to the PD-1/PD-L1 pathway in blood can be used as potential diagnostic and prognostic markers [13]. PD-L1 is also expressed by macrophages in ovarian cancer and is strongly associated with both effector and regulatory tumour infiltrating lymphocyte (TIL) subsets [14]. Interestingly, Yang et al. revealed a previously unrecognized mechanism through which chemotherapy induces tumour immune evasion via the up-regulation of PD-L1 in bone marrow stromal cells, providing new evidence for the combination of chemotherapy and anti-PD-L1/PD-1 as an effective strategy for the treatment of lymphoma and other cancers [15].

Although PD-L1 is a potent negative regulator of anti-tumour immunity, little known is known about how cytoplasmic and membranous PD-L1 are regulated by the tumour microenvironment in ovarian cancer. The results of the present study showed that soluble inflammatory factors derived from tumour-associated macrophages (TAM) induced membrane-bound PD-L1 of cancer cells and subsequently induced these cells to immune escape. The present study also showed that PD- $1^{+} \mathrm{CD} 8^{+} \mathrm{T}$ cells accumulated in the tumour microenvironment, and decreased PD $-1^{+} \mathrm{CD} 8^{+} \mathrm{T}$ cells were associated with the ability of PD-1 and PD-L1 mAbs to cause tumour regression. This observation, along with the infiltration patterns of immune cells in tumour samples, indicated that TAM-induced membranous PDL1 on ovarian cancer cells represented an innovative mechanism through which cancer cells evaded immune destruction.

\section{Materials and Methods}

\section{Patients}

The 87 patients analysed in the present study were treated at the Department of Obstetrics and Gynaecology, the First and Second Affiliated Hospital of Soochow University from 2006 to 2014. A total of 81 women had ovarian carcinoma, and 6 women had benign cystadenoma. The mean age at diagnosis was 52.9 years in the carcinoma group and 33.5 years in the benign group. Informed consent was obtained from all participants. The study was approved through the committee for medical and health research ethics of the First Affiliated Hospital of Soochow University. All methods and animal experiment protocols were approved and performed in accordance with the relevant guidelines and regulations of the committee for medical and health research ethics of the First Affiliated Hospital of Soochow University.

\section{Cell lines}

The ovarian cancer cell line (H0890 and SKOV3) was obtained from the Chinese Academy of Sciences, Shanghai Institutes for Biological Sciences. The mouse ovarian cancer cell line (ID8) was a kind gift from Prof. Binfeng Lu (Department of Immunology, University of Pittsburgh). The cells were cultured in RPMI 1640 medium supplemented with $10 \%$ foetal bovine serum (FBS), $2 \mathrm{mM} \mathrm{L-glutamine,} 100 \mathrm{U} / \mathrm{mL}$ penicillin, $100 \mathrm{mg} / \mathrm{mL}$ streptomycin, and $50 \mathrm{mM}$ 2-ME. The cell line was incubated at $37^{\circ} \mathrm{C}$ with $5 \% \mathrm{CO}_{2}$. The cells were authenticated and assessed for mycoplasma. All medium and supplements were obtained from Gibco BRL Life Technologies. 


\section{Cellular Physiology Cell Physiol Biochem 2017;43:1893-1906 \begin{tabular}{l|l} 
and Biochemistry 10.1159/000484109 20,2017 & $\begin{array}{l}\text { (C) 2017 The Author(s). Published by S. Karger AG, Basel } \\
\text { www.karger.com/cpb }\end{array}$ \\
\hline
\end{tabular} \\ Publisned ont Expression of PD-L1 in Ovarian Cancer Cells}

\section{Abs and reagents}

Phycoerythin (PE)-conjugated anti-human PD-L1 mAb, fluorescein isothiocyanate (FITC)-conjugated anti-human IL-10, IL-6, TNF- $\alpha$, IFN- $\gamma$ and CD68 were purchased from eBioscience (San Diego, CA). Recombinant human IL-6, IL-10, IFN- $\gamma$ and TNF- $\alpha$ were obtained from R\&D Systems (Minneapolis, MN). The Fixation/Permeabilization Solution Kit with BD GolgiStop ${ }^{\mathrm{TM}}$ was obtained from BD Biosciences (San Diego, CA). Purified anti-human PD-L1 antibody and purified anti-mouse PD-L1 (MIH5) and PD-1 antibodies (J43) were purchased from eBioscience. Primary antibodies included anti-p-ERK1/2, anti-p-serine/threonine kinase (AKT), and anti-p-signal transducer and activator of transcription 3 (STAT3) were obtained from Cell Signalling Technology. Phorbol 12-myristate 13-acetate (PMA) and ionomycin were purchased from SigmaAldrich. The AKT inhibitor LY294002 and ERK1/2 inhibitor PD98059 were purchased from Beyotime (Nantong, China).

\section{Detection of PD-L1 mRNA transcription using reverse transcription PCR (RT-PCR)}

The mRNA was extracted from H08910 and SKOV3 cells using Trizol reagent (Gibco, Life Technologies) according to the manufacturer's instructions. Random primer and Reverse Transcriptase (MBI) were used to synthesize cDNA according to routine methods. Polymerase chain reaction (PCR) cycling conditions were $94^{\circ} \mathrm{C}$ for $5 \mathrm{~min}$, followed by 35 cycles at $94^{\circ} \mathrm{C}$ for $45 \mathrm{sec}, 54^{\circ} \mathrm{C}$ for $45 \mathrm{sec}$, and $72^{\circ} \mathrm{C}$ for $45 \mathrm{sec}$, with a final cycle at $72^{\circ} \mathrm{C}$ for $10 \mathrm{~min}$. Subsequently, the PCR products were separated on $1 \%$ agarose gel and visualized through ethidium bromide staining. The amplification of $\beta$-actin mRNA was conducted as a control.

\section{Flow Cytometry}

The surface expression of PD-L1 on H08910, SKOV3 and primary tumour cells was quantified using FCM. The cells were also analysed for PD-L1 expression using intracellular staining. Briefly, single-cell suspensions were collected and stained with PE-conjugated anti-PD-L1 mAbs. For intracellular staining, the cells were fixed using Fixation/Permeabilization solution for $12 \mathrm{~min}$ at $4^{\circ} \mathrm{C}$. Subsequently, the cells were washed using BD Perm/Wash Buffer and stained with PE-conjugated anti-PD-L1 mAbs for 15 min at $4^{\circ} \mathrm{C}$.

\section{Immunohistochemistry}

Representative formalin-fixed and paraffin-embedded sections were reviewed for immunohistochemistry. Briefly, 4-mm-thick sections were mounted on Superfrost microscopic slides, deparaffinized, and dehydrated. Antigen retrieval was performed through pressure-cooking. The slides were incubated with antibodies directed against the following proteins: CD68 (KP1, MXB) and PD-L1 (Novus), and IL-10, IL-6, TNF- $\alpha$ and IFN- $\gamma$ (Abcam). PD-L1 staining was evaluated based on cytoplasmic/membranous positivity. The presence of PD-L1 expression in stromal cells from ovarian samples could be excluded from immunohistochemical data by virtue of specific histomorphological features and topographic locations in tissue sections. TAM was identified as CD68-positive staining and manually counted on consecutive sections at high-power magnification. To control for inter-observer variation, two observers evaluated randomly selected cases.

\section{Treatment of ovarian cell in vitro and in vivo}

In short, human ovarian carcinoma tissue samples were cut into small pieces and digested in RPMI 1640 media supplemented with $0.2 \mathrm{mg} / \mathrm{mL}$ Liberase TL (Roche) and $0.3 \mathrm{mg} / \mathrm{mL}$ DNase I (Sigma-Aldrich) at $37^{\circ} \mathrm{C}$ for $30 \mathrm{~min}$. The dissociated cells were filtered and separated through Ficoll centrifugation. The mononuclear cells were washed and re-suspended in PBS supplemented with 1\% FBS. Subsequently, CD14+ cells were isolated using positive selection (Miltenyi Biotec). The mononuclear cells and CD $14^{+}$cells were cultured in RPMI-1640 medium supplemented with 10\% FBS for $24 \mathrm{~h}$, and subsequently, the supernatant of mononuclear cells (SN-T) and CD14+ cells (SN-TAM) were collected to respectively stimulate SKOV3 cells $\left(2 \times 10^{5}\right.$ cells/well). The SKOV3 cells were also cultured in the presence of IL-10, IL-6, TNF- $\alpha$ or IFN- $\gamma$ for 96 $\mathrm{h}$.

Nude mice were subcutaneously injected with SKOV3 cells $\left(5 \times 10^{6}\right.$ cells per mouse). Two weeks following tumour implantation, the mice were sacrificed, and the tumours were harvested. For primary tumour cells, human epithelial cell adhesion molecule (EpCAM) ${ }^{+}$cells were gated to analyse PD-L1 expression. To purify SKOV3 cells, digestion exclusion and repeated adherence were performed to eliminate other cells during cell culture. We also confirmed the primary tumour cells using an implanted tumours assay. 


\section{Cellular Physiology Cell Physiol Biochem 2017;43:1893-1906 and Biochemistry Published \begin{tabular}{l|l} 
DOI: 10.1159/000484109 2017 The Author(s). Published by S. Karger AG, Basel \\
(c) 2017 ww.karger.com/cpb
\end{tabular}}

Qu et al.: Expression of PD-L1 in Ovarian Cancer Cells

\section{Intracellular cytokine staining of TAMs}

TAMs isolated from human ovarian cancer tissue (Miltenyi Biotec) were re-stimulated with PMA (50 $\mathrm{ng} / \mathrm{mL})$ and ionomycin $(1 \mu \mathrm{g} / \mathrm{mL})$ for $1 \mathrm{~h}$, and plated in the presence of BD GolgiStop protein transport inhibitor (containing Monensin) for $4 \mathrm{~h}$. Subsequently, the cells were fixed and permeabilized in Fixation/ Permeabilization solution and stained with FITC-anti-IL-10, IL-6, TNF- $\alpha$ and IFN- $\gamma$ according to the manufacturer's instructions.

\section{Real-time PCR}

The SKOV3 cells treated with IL-10, IL-6, TNF- $\alpha$, IFN- $\gamma$ and SN-TAM were harvested. After synthesis via routine methods, cDNA was subjected to qPCR using the iCycler (Bio-Rad, USA) with SYBR Green (Bio-Rad, USA) as a fluorescent reporter. PD-L1 and $\beta$-actin cDNAs were amplified in separate reactions. The threshold cycle number was determined using iCycler software, and the levels of PD-L1 expression were normalized

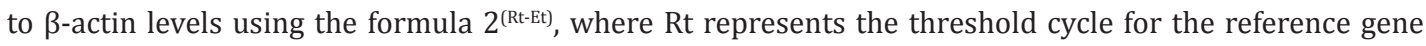
( $\beta$-actin) and Et is the threshold cycle for the experimental gene (PD-L1). The data are thus expressed as arbitrary units.

\section{Western blot and signal transduction analyses}

Cell lysates were prepared in a RIPA buffer. After protein quantitation, equal amounts of proteins were separated using sodium dodecyl sulphate polyacrylamide gel electrophoresis, and blotted onto PVDF membranes. The membrane was blocked with $5 \%$ bovine serum albumin in phosphate buffer solution containing Tween-20 (PBST) (PBS, pH 7.5, containing 0.1\% Tween-20), and incubated with rabbit anti-human p-ERK1/2 (1:2000), p-AKT (1:2000) and p-STAT3 (1:1000) antibodies overnight at $4^{\circ} \mathrm{C}$. The membrane was subsequently washed with PBST and incubated with goat anti-rabbit secondary antibody for one hour at room temperature. To explore the signal transduction pathway involved in PD-L1 expression, the following cytokines and reagents were used: PD98059 ERK1/2 inhibitor (10 $\mu \mathrm{M})$, LY294002 AKT inhibitor (10 $\mu \mathrm{M})$, recombinant human IFN- $\gamma(100 \mathrm{ng} / \mathrm{mL})$, and recombinant human TNF- $\alpha(100 \mathrm{ng} / \mathrm{mL})$.

\section{Apoptotic assays of $T$ cell}

$\mathrm{CD}^{+} \mathrm{T}$ cells were isolated using positive selection from malignant ascites resulting from ovarian carcinomas. SKOV3 cells were plated onto 6 -well plates at a density of $2 \times 10^{5}$ cells/well and cultured in the absence or presence of supernatants from TAMs for $72 \mathrm{~h}$ to induce PD-L1 expression. After washing the cells, freshly tumour-associated CD8 ${ }^{+} \mathrm{T}$ cells were added. Where indicated, anti-PD-L1 mAb or respective control antibodies (isotype) were added to the co-culture system to delineate the functional relevance of PD-L1 for tumour-immune cell interactions. Apoptosis was assessed via Annexin-V staining. Briefly, $1 \times 10^{6}$ cells were washed twice in PBS and resuspended in $100 \mu \mathrm{L}$ of labelling solution containing $2 \mu \mathrm{L}$ of Annexin-V and PEanti-CD8 $\mathrm{mAb}$ for $15 \mathrm{~min}$ at room temperature.

\section{siRNA silencing and PD-1-Ig cross-linking}

To down-regulate PD-L1 expression in SKOV3 and H08910 cells, three specific siRNA duplexes targeting PD-L1 were synthesized at GenePharma Co. Ltd. (Suzhou, China), and duplexes with nonspecific sequences were used as negative controls (NCs). siRNA\#1: 5'-GCCGAAGUCAUCUGGACAATT-3', 5'-UUGUCCAGAUGACUUCGGCTT-3'. SiRNA\#2: 5'-CCAGCACACUGAGAAUCAATT-3', 5'-UUGAUUC UCAGUG UGCUGGTT-3'. siRNA\#3: 5'-CUGGGAGCC AUCUUAUUAUTT-3', 5'-AUAAUAAGAUGGCUCCCAGTT-3'. siRNANC: 5'-UUCUCCGAACGUGU CACGUTT-3', 5'-ACGUGACACGUUCGGAGAATT-3'. Ovarian cancer cells were transfected with siRNA using Lipofectamine 2000 (Invitrogen, CA, USA). The transfection efficiency was examined using qPCR and Western blot analyses. H08910 cells were plated onto 6-well plates at a density of $2 \times 10^{5}$ cells/well and cultured in the presence of PD-1-Ig (100 and $\left.500 \mathrm{ng} / \mathrm{ml}\right)$ for $72 \mathrm{~h}$.

\section{Cell growth and migration assays}

Cancer cell growth was analysed using a CCK- 8 assay. The migration assay was performed using a Transwell assay (Costar, NY, pore size, $8-\mu \mathrm{m}$ ) in 24-well dishes. Approximately $2 \times 10^{4}$ cells in $100 \mu \mathrm{L}$ of serum-free RPMI-1640 medium were placed in the upper chamber, and $500 \mu \mathrm{L}$ of the medium with $10 \%$ FBS was placed in the lower chamber. The plates were incubated for $12 \mathrm{~h}$ at $37^{\circ} \mathrm{C}$ in $5 \% \mathrm{CO}_{2}$, and subsequently the cells were fixed in methanol for 15 min and stained with $0.05 \%$ crystal violet in PBS for 15 min. Cells on 


\section{Cellular Physiology Cell Physiol Biochem 2017;43:1893-1906

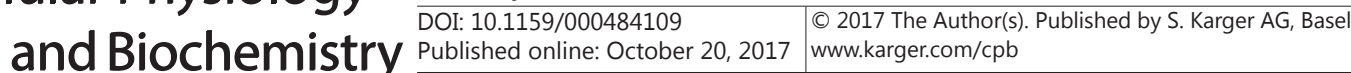

Qu et al.: Expression of PD-L1 in Ovarian Cancer Cells

the upper side of the filters were removed with cotton-tipped swabs, and the filters were washed with PBS. The cells on the underside of the filters were examined and counted under a microscope. Each clone was plated in triplicate in each experiment, and each experiment was repeated at least three times.

In vivo experiments

Mice were injected subcutaneously with $2 \times 10^{4}$ ID 8 cells per mouse (C57BL/6). $4 \mathrm{~d}$ after injection, the tumour-bearing mice were either treated with IgG or PD-L1 mAb (100 $\mu \mathrm{g} / \mathrm{mouse})$ or PD-1 mAb (100 $\mu \mathrm{g}$ /mouse) subcutaneously in $100 \mu \mathrm{L}$ of PBS. The tumour sizes were assessed in a blind, coded manner every two or three days. Tumour volume was calculated using the following formula: tumour volume $=0.5 \times\left[\right.$ length $(\mathrm{mm}) \times$ width $\left.(\mathrm{mm})^{2}\right]$. The mean of 6 mice per group is indicated in the graphs. Subsequently, the spleen, peripheral blood and draining lymph nodes were isolated for cytometric analysis.

\section{Statistical analysis}

Statistical analyses were performed using the SPSS statistical software program, version 17.0 (SPSS Inc., Chicago, IL). The values are presented as the means \pm SD, and the differences between groups were assessed using variance analysis. Statistical significance was determined using two-tailed unpaired Student's t test or one-way analysis of variance. A value of $P<0.05$ was considered statistically significant. Only serous versus non-serous tumours were histologically analysed.

\section{Results}

\section{Expression of PD-L1 in ovarian cancer cells in vivo and in vitro}

First, we examined the levels of PD-L1 mRNA in SKOV3 and H08910 cells, and the results showed that both SKOV3 and H08910 cells were positive for PD-L1 transcription. Flow cytometry analysis was used to quantify the cell surface and intracellular fractions of PD-L1 protein across different ovarian cancer cell lines (Fig. 1A, B). Intriguingly, SKOV3 and H08910 cells exhibited significantly high levels of cytoplasmic PD-L1 expression, and notably, H08910 cells were positive for the surface staining of the PD-L1, whereas SKVO3 cells were negative for this staining.

The current study also demonstrated that membranous and cytoplasmic PD-L1 staining was detected in surgical resection specimens of ovarian cancer. Overall, PD-L1 cytoplasmic staining was detected in 45/81 samples, membrane staining was detected in 22/81 samples, PD-L1 co-staining in the cytoplasm and membrane was observed in 13/81 cases (Fig. 1C, Table 1).

The absence of $T$ and $B$ cells does not influence the tumour microenvironment mediating the inducible expression of membranous $P D-L 1$

Next, we performed a series of in vitro and in vivo experiments to explore the surface expression of PD-L1 on ovarian cancer cells. SKOV3 cells were treated with SN-T. As expected, SN-T induced the surface expression of PD-L1 on SKOV3 cells. To determine whether these effects on cancer cells were transient, SKOV3 cells treated with SN-T were plated ex vivo overnight with regular medium (Re-medium). Subsequently, the PD-L1 expression returned to baseline after the removal of SN-T (Fig.

2A, B).

To investigate whether inducible PDL1 expression on SKOV3 cells is required for $\mathrm{T}$ cells or B cells, we used tumour models established in nude mice in which $\mathrm{T}$ cells and $\mathrm{B}$ cells were deficient, while most of the other immune cells were intact. These experiments showed that the education in nude mice could induce an increase of surface-bound PD-L1
Table 1. Correlation between PD-L1 expression and immune cell infiltration in ovarian carcinomas

\begin{tabular}{lrrrrrr}
\hline PD-L1 & $\begin{array}{c}\text { CD68+cell } \\
\text { infiltration } \\
\text { High }\end{array}$ & low & & $\begin{array}{c}\text { CD8 } \\
\text { infiltration } \\
\text { High }\end{array}$ & low & cell \\
\hline $\begin{array}{l}\text { Membrane } \\
\quad \text { Strong }\end{array}$ & 19 & 3 & $0.030^{*}$ & 10 & 12 & 0.116 \\
$\quad$ Low & 36 & 23 & & 16 & 43 & \\
Cytoplasm & & & & & & \\
$\quad$ Strong & 33 & 12 & 0.242 & 19 & 26 & $0.029^{*}$ \\
$\quad$ Low & 22 & 14 & & 7 & 29 & \\
\hline
\end{tabular}




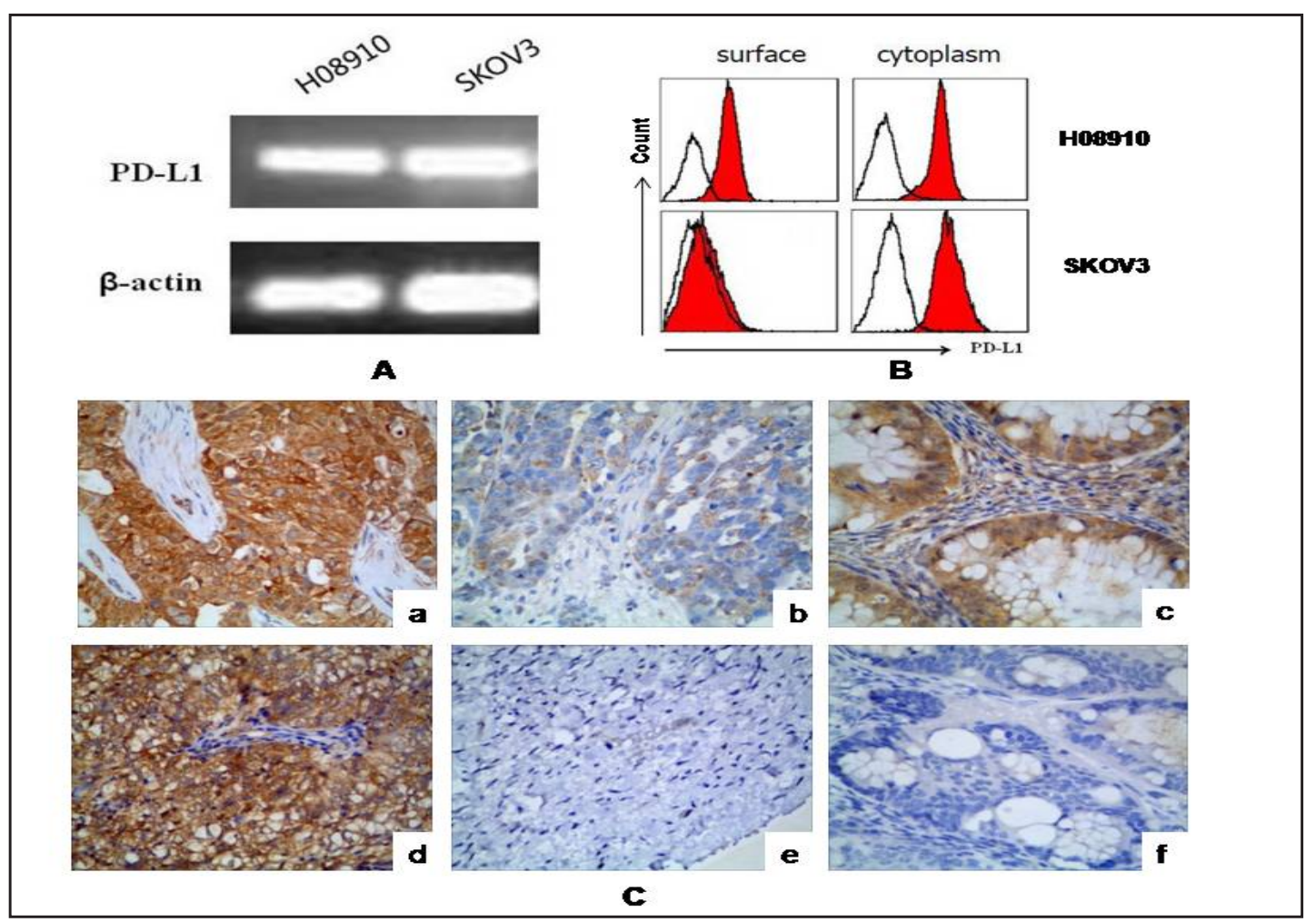

Fig. 1. RT-PCR (A) and flow cytometry analysis (B) were used to-determine the PD-L1 mRNA, the cell surface and intracellular fractions of PD-L1 protein across the different cell lines (HO8910 and SKOV3). Subcellular localization of PD-L1 in ovarian carcinomas was analysed using immunohistochemistry (C). Tumour cells were heterogeneous with respect to the expression of PD-L1 protein, whose expressions pattern included (a) cytoplasm ${ }^{\text {high }}$ membrane $\mathrm{e}^{\text {high }}$, (b) cytoplasm ${ }^{\text {low }}$ membrane $e^{\text {low }}$, (c) cytoplasm ${ }^{\text {high }}$, and (d) membrane chigh $^{\text {There }}$ was a significant difference in the expression of PD-L1 between carcinomas and benign cystadenoma (e). Isotype IgG was used as a control (f). Representative staining of PD-L1 is shown.

protein on SKOV3 cells. Subsequently, membranous PD-L1 expression on SKOV3 cells was also down-regulated when the tumour microenvironment was removed (Fig. 2C, D).

TAM-derived inflammatory cytokines induced PD-L1 expression on surface of ovarian cancer cells

Next, we hypothesized that the membranous PD-L1 expression reflects the infiltration of TAMs. To this end, we used human cancer samples obtained from ovarian cancer patients. Semi-quantitative IHC analysis showed that membranous PD-L1 was positively correlated with infiltrated TAMs. To further substantiate these findings, SKOV3 cells were treated with SN-T or SN-TAM in vitro. Alternatively, SN-T and to some degree SN-TAM, induced the surface expression of PD-L1 (Fig. 3A). Having demonstrated that TAMs increased membranous PD-L1 expression, we subsequently investigated the molecular mechanism underlying the regulation of PD-L1 expression in TAMs.

We profiled the cytokine expression in ovarian cancer, borderline tumours and benign tumours using immunochemistry (Fig. 3B). An important finding is that ovarian cancers have a higher frequency of IFN- $\gamma$, TNF- $\alpha$, IL-10 and IL- 6 associated with detectable TAMs. Furthermore, flow cytometric analysis and intracellular cytokine staining of TAMs from ovarian tumours largely validated these data and provided additional quantitative information, demonstrating that TAMs are characterized in a subpopulation of cells as IFN- $\gamma$, TNF- $\alpha$, IL-10 and IL-6 secreting (Fig. 3C).

\section{KARGER}




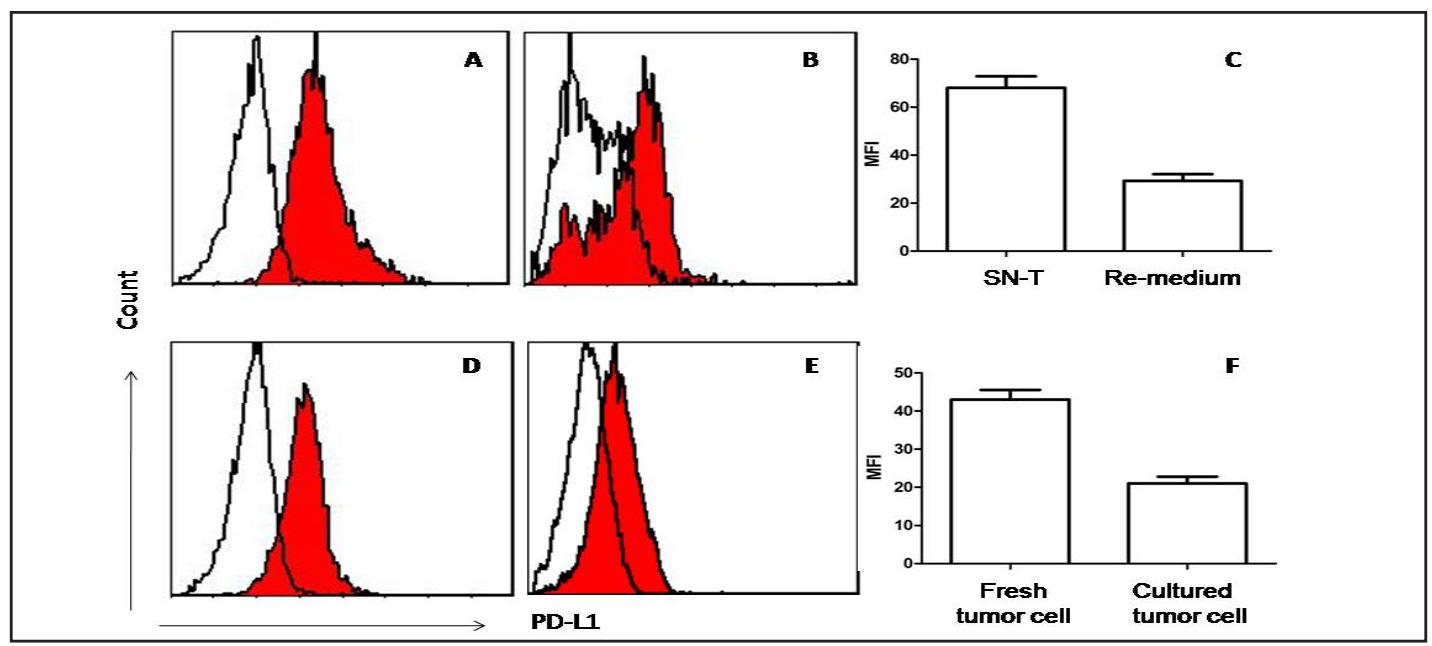

Fig. 2. The education in vitro and in vivo resulted in a significant increase in the proportion of surface PDL1 protein on tumour cells, which returned to baseline after removal from the tumour microenvironment. SKOV3 cells treated with SN-T (A) were plated ex vivo overnight with Re-medium (B). Fresh SKOV3 cells isolated from tumour-bearing mice (D) were cultured in Re-medium (E). Flow cytometry analysis was used to determine the PD-L1 expression on the surface of SKOV3 cells, and the mean fluorescence intensity (MFI) was used to qualify the data (C, F).

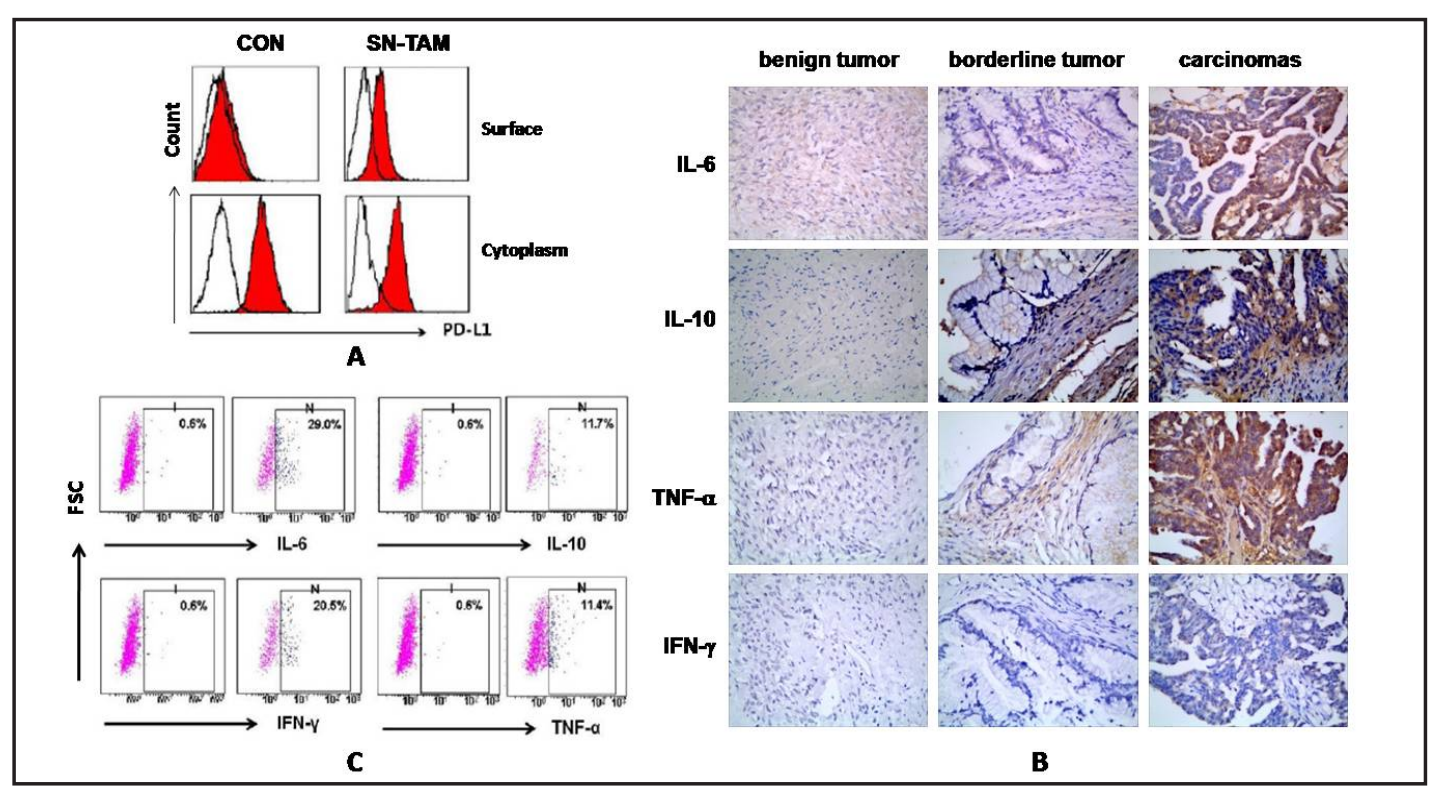

Fig. 3. SKOV3 cells treated with supernatant retained from TAMs (SN-TAM) were analysed for PD-L1 expression using Flow cytometry analysis (A). Immunochemistry assay showed a significant difference in the expression of IFN- $\gamma$, TNF- $\alpha$, IL-10 and IL- 6 between carcinomas, borderline tumours and benign tumours (B). Intracellular cytokine staining showed that IFN- $\gamma$, TNF- $\alpha$, IL-10 and IL- 6 was distributed in the cytoplasm of TAMs (C).

Next, we determined whether elevated PD-L1 is associated with the treatment of IFN- $\gamma$, TNF- $\alpha$, IL-10 and IL-6. As expected, SN-TAM and to a lesser degree, IFN- $\gamma$, TNF- $\alpha$, IL-10 and IL-6 could promote membrane-bound PD-L1 protein expression, but did not alter its intracellular levels (Fig. 4A). These data suggest that TAMs exhibit the pronounced function of regulating PD-L1 expression.

\section{KARGER}


Fig. 4. A, Membranous PD-L1 expression was increased in SKOV3 cells after co-culture with IFN- $\gamma$, TNF- $\alpha$, IL-10 and IL-6, and cytoplasmic PD-L1 was not altered after treatment. B, qPCR showed that PD-L1 mRNA expression was not upregulated in SKOV3 cells after co-culture with cytokines, $\mathrm{P}>0.05$. C, Western blot assays showed that cytokines and TAMs induced membranous PDL1 expression, reflecting increasing amounts of total protein expression.

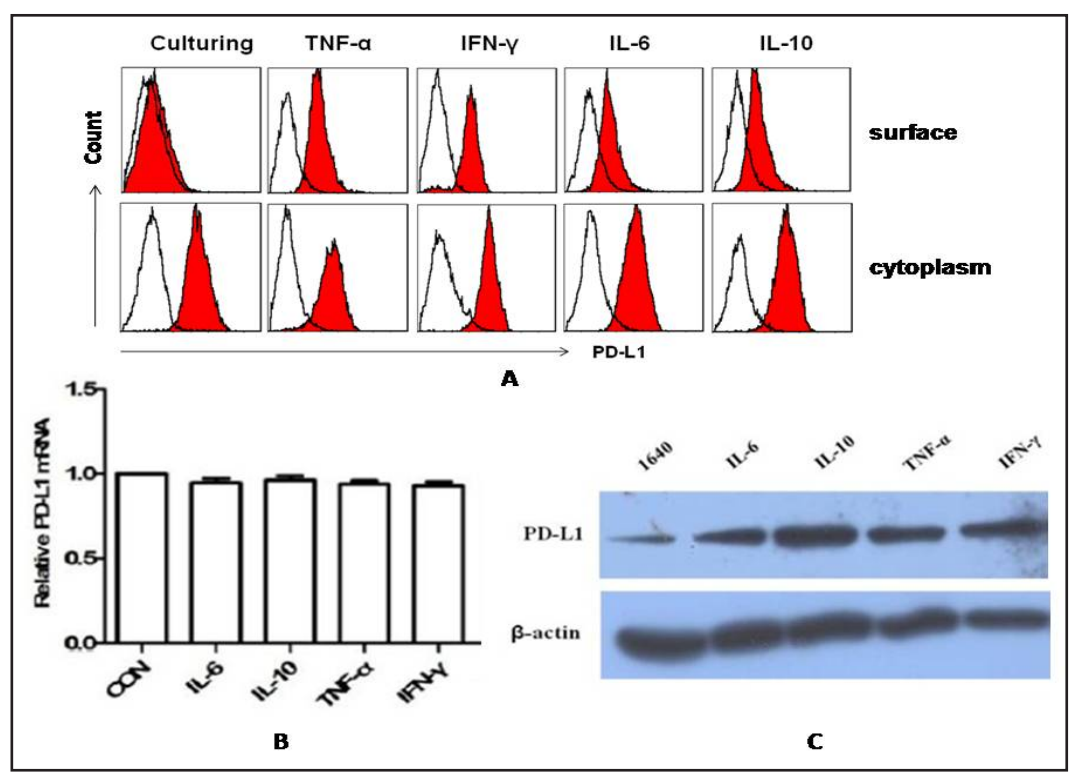

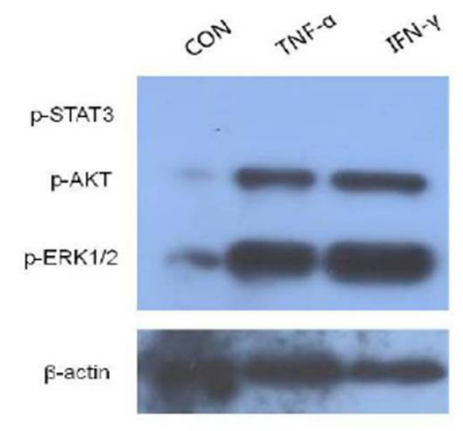

A

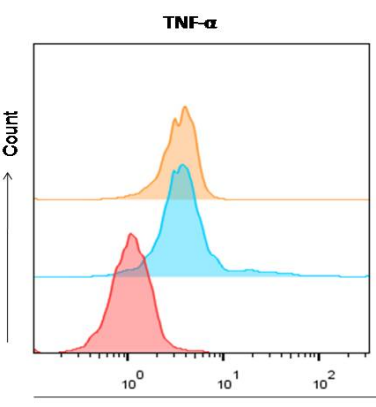

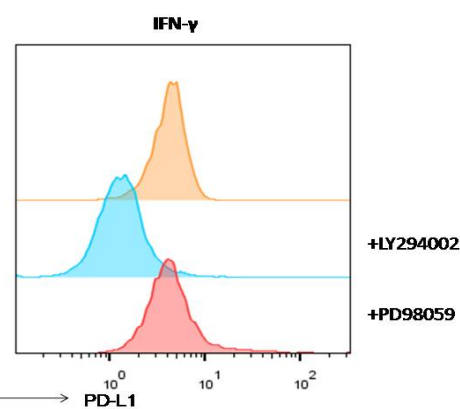

C

Fig. 5. Signal transduction assay. A, Western blot showing that the phosphorylation of ERK1/2 and AKT was mediated by TNF- $\alpha$ and IFN- $\gamma$. B and C, ERK1/2 inhibitor PD98059 (red line) treatment significantly reduced TNF- $\alpha$ (B, yellow line) induced surface PD-L1 protein expression, and AKT inhibitor LY294002 (blue line) treatment significantly reduced IFN- $\gamma$ (C, yellow line) induced surface PD-L1protein expression in SKOV3 cells, respectively.

To understand the underlying mechanisms of membranous PD-L1 expression, we characterized SKOV3 cells in the context of IFN- $\gamma$, TNF- $\alpha$, IL-10, IL-6 and SN-TAM. Initially, we observed that PD-L1 mRNA expression was not up-regulated in SKOV3 cells treated with SN-TAM or IFN- $\gamma$, TNF- $\alpha$, IL-10 and IL-6 for $24 \mathrm{~h}(P>0.05$, Fig. 4B). According to Western blot assays, inducible membrane-bound PD-L1 expression reflected increasing amounts of total protein expression, but not a shift in the proportion of surface versus intracellular proteins (Fig. 4C).

This finding led us to explore whether the signal pathways in cancer cells could be induced at a higher level upon TAM-associated cytokine treatment. A stronger effect of IFN- $\gamma$ and TNF- $\alpha$ on membranous PD-L1 expression prompted us to further investigate whether IFN $-\gamma$ and TNF- $\alpha$ had a similar function in signal transduction in cancer cells. As shown in Fig. 5, as a consequence, the phosphorylation of ERK1/2 and AKT were both observed after TNF- $\alpha$ or IFN- $\gamma$ treatment in SKOV3 cells, but treatment with the ERK1/2 inhibitor 


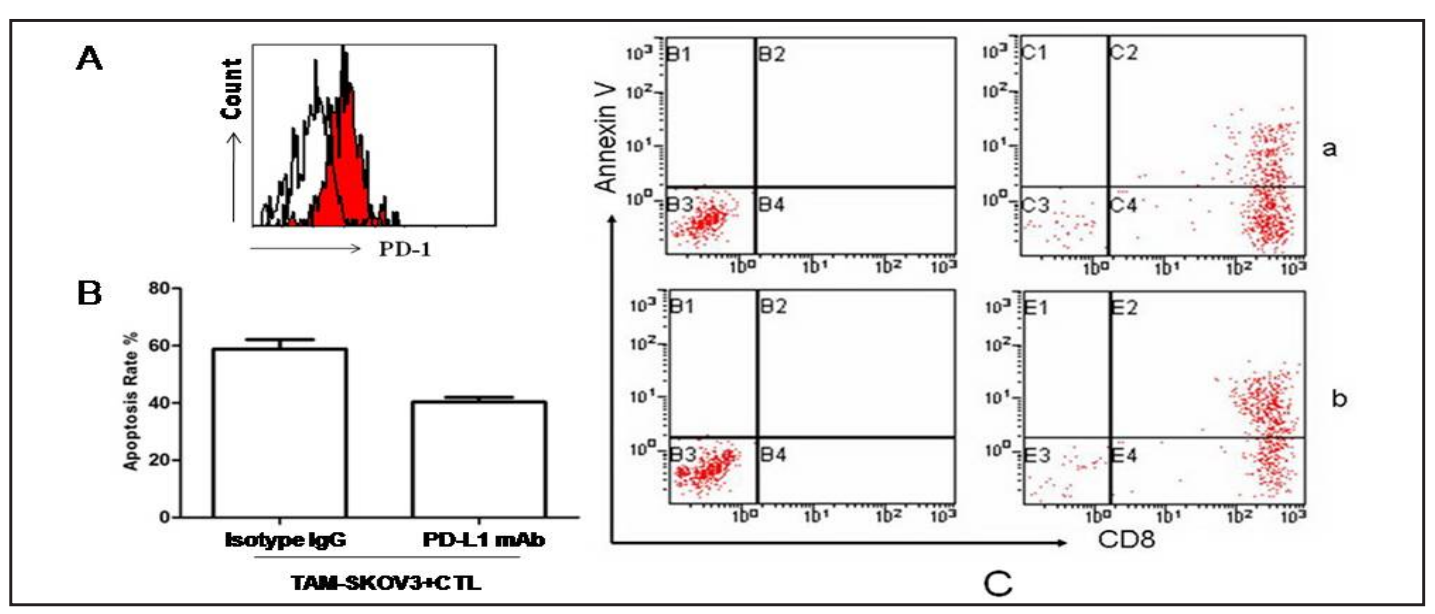

Fig. 6. Ovarian cancer cell-associated PD-L1 mediated CD8 ${ }^{+} \mathrm{T}$ cell apoptosis. A, Membranous PD-1 was expressed by tumour infiltrated $\mathrm{CD}^{+} \mathrm{T}$ cell. B and C, Inducible PD-L1 expressions promoted CD8 ${ }^{+} \mathrm{T}$ cell apoptosis in vitro ( $a$, control, $b, P D-L 1 \mathrm{mAb}, \mathrm{P}<0.05)$.

PD98059 only significantly reduced TNF- $\alpha$-induced surface PD-L1 protein expression, and the AKT inhibitor LY294002 only significantly reduced IFN- $\gamma$-induced surface PD-L1 protein expression in SKOV3 cells.

\section{Inducible membranous PD-L1 mediated CTL apoptosis}

To investigate the functional significance of the induced surface PD-L1 expression on SKOV3 cells, we performed co-culture experiments with $\mathrm{CD}^{+} \mathrm{T}$ cells in the absence or presence of a blocking antibody against PD-L1. Interestingly, tumour-infiltrating CD8 ${ }^{+} \mathrm{T}$ cells expressed the PD-L1 receptor PD-1, suggesting that tumours might regulate T cell function via PD-1 signals. When co-cultured with TAM-treated-SKOV3 cells, $30 \%$ of the CD8 ${ }^{+}$T population underwent apoptosis. In the presence of anti-PD-L1 antibody, 15\% of the CTL population underwent apoptosis. Overall, antibodies against PD-L1 inhibited the apoptosis of $\mathrm{T}$ cells by $50 \%(P<0.05$, Fig. 6$)$. These results thus suggested that exposure to PD-L1 is responsible for the apoptosis of $\mathrm{T}$ cells.

\section{Cytoplasmic PD-L1 suppresses ovarian cancer cell growth}

The detection of PD-L1 in the cytoplasm but not on the membranes of SKOV3 cells suggested that his protein might have an unexpected function, different from what has previously been described for its membranous counterpart. Thus, the expression of PD-L1 in SKOV3 was silenced by transient transfection with PD-L1-specific siRNA. Fig. 7A shows that among these three candidates, siRNA\#1 could effectively reduce PD-L1 mRNA in SKOV3 cells, while scramble siRNA (siRNA -NC) had no effect on PD-L1 expression. Western blot analysis also confirmed that the PD-L1 protein in SKOV3 cells was significantly reduced using siRNA\#1 (Fig. 7B). These data indicated that siRNA\#1 could inhibit PD-L1 expression in SKOV3 cells, thus this molecule was used in subsequent experiments.

We determined whether the silencing of cytoplasmic PD-L1 influenced the growth and migration of ovarian cancer cells in vitro. PD-1-Ig treatment was examined using H08910 cell lines to investigate whether cross-linking could induce cell death though membranous PD-L1. As shown in Figures 7C and D, PD-L1 siRNA significantly reduced the growth and inhibited the migration of SKOV3 cells according to CCK-8 and transwell assays, respectively $(P<0.05)$. However, PD-L1 cross-linking with PD-1-Ig did not influence the growth and migration of H08910 cells ( $P>0.05$, Fig. 7E and F). These findings suggested that PD-L1induced cell growth inhibition was not dependent on the cross-linking of membranous PDL1, but the intrinsic potential of cytoplasmic PD-L1. 
Fig. 7. The role of cytoplasmic PD-L1 in the growth of ovarian cancer cells. Real-time PCR (A) and western blotting (B) was used to confirm the efficacy of siRNA on PD-L1 expression in ovarian cancer cells. CCK-8 and transwell assays were used to analyse cell growth (C) and migration (D) in vitro, $\mathrm{P}<0.05$. PD-1Ig treatment demonstrated that PD-1-Ig cross-linking did not induce cell growth (E) and migration (F), $\mathrm{P}>0.05$.

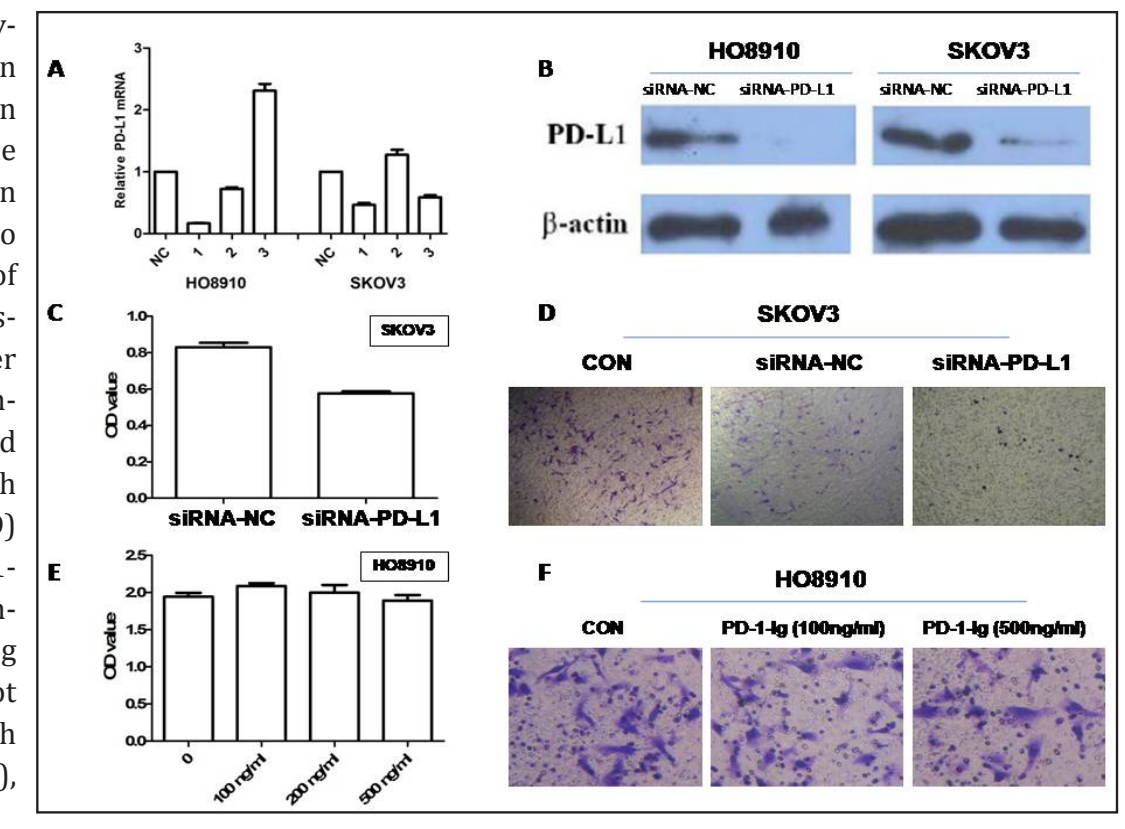

Fig. 8. Experiments of tumour growth and immune response in vivo. A, The mice injected with SKOV3 cells showed progressive tumour growth, and tumour-bearing mice injected with PD-L1 mAb or PD-1 mAb showed slow tumour growth $(\mathrm{P}<0.05)$. No difference between the PD-L1 mAb and PD-1 $\mathrm{mAb}$ groups was observed ( $P>0.05)$. Two-tailed unpaired Student's t test was used for the analysis of tumour growth. PD$1^{+} \mathrm{CD}^{+} \mathrm{T}$ cell was increased in the tumours (B). C, PD- $1^{+} \mathrm{CD} 8^{+} \mathrm{T}$ cell was analysed in the spleen, peripheral blood (PB) and draining lymph nodes (LN) isolated from mice.

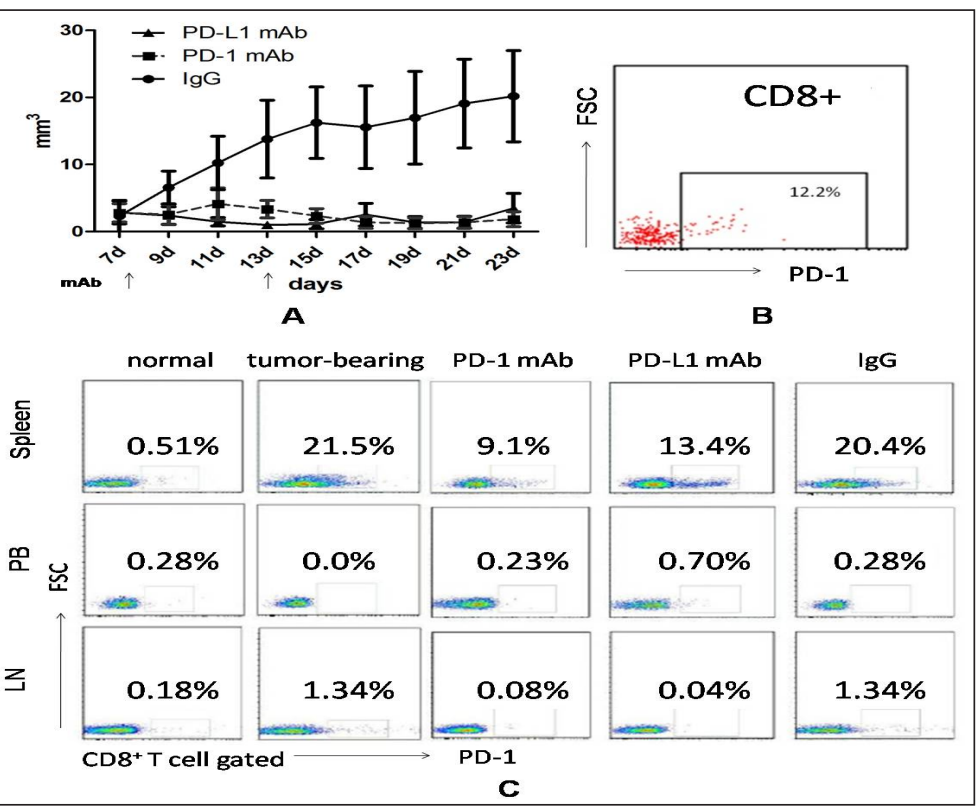

\section{Experiments of tumour growth and immune response in vivo}

We also examined the effect of a mAbs specifically directed against mouse PD-L1 or PD-1 on adoptive therapy for ID8-bearing mice. As shown in Fig. 8, mice injected with ID8 cells showed progressive tumour growth, and tumour-bearing mice injected with PD-L1 or PD-1 mAbs showed slow tumour growth $(P<0.05)$. Subsequently, we isolated the spleen, peripheral blood and draining lymph nodes from mice to analyse the PD- $1^{+} \mathrm{CD} 8^{+} \mathrm{T}$ cells. Among all groups (normal mice, tumour-bearing mice, PD-L1 mAb or PD-1 mAb-treating mice), peripheral blood and draining lymph nodes showed low levels of PD- $1^{+} \mathrm{CD} 8^{+} \mathrm{T}$ cell infiltration. Notably, higher levels of $\mathrm{PD}-1^{+} \mathrm{CD} 8^{+} \mathrm{T}$ cells were present in the spleens of tumourbearing mice, and PD-L1 mAb or PD-1 mAb injection showed potential to decrease the PD$1^{+} \mathrm{CD} 8^{+} \mathrm{T}$ cell population in the spleen. 


\section{Discussion}

Tumours evade antitumour immune responses and $\mathrm{T}$ cell-based immunotherapies through multiple intratumour factors, such as suppressive antigen-presentation by TAMs, T cell apoptosis-inducing PD-L1, and regulatory cytokines. These factors are enriched in many solid tumours, but the mechanism for their initial formation inside the tumour is still unclear.

PD-L1 has been the most notable biomarker in tumour research in the past decade. Previous studies have reported data regarding the association between PD-L1 status and prognosis in cancer, indicating a worse outcome and late stage for patients with high PD-L1 expression [16-20]. Studies have indicated that PD-1 and PD-L1 molecules are biologically relevant regulators of the immune response in high-grade serous ovarian carcinoma, highlighting the need for the evaluation of immune checkpoint inhibiting drugs in this tumour entity [21]. Recently, PD-L1/PD-1 pathway-targeted therapy has been extensively studied in various human malignant tumours [22-24]. Innovative effective therapies would be of great benefit against ovarian cancer, and immunotherapy, in particular, would offer alternatives to current treatment strategies.

The mechanism by which PD-L1 surface expression is induced is quite ambiguous, including immune cells and cancer cells. In addition to adaptive PD-L1 up-regulation in an inflammatory cytokine milieu, tumours show an innate potential to drive PD-L1 expression through oncogenes. For example, the induction of PD-L1 expression on macrophages through IL-10 has been observed in solid tumours, including hepatocellular carcinoma and glioma, both of which foster the development of immune privilege in the tumour $[25,26]$. PD-L1 is also up-regulated through dynamic IFN- $\gamma$ expression during antitumour immune responses [27]. Several genetic alterations are associated with constitutive PD-L1 upregulation. PD-L1 is also over-expressed in cancer cells under the influence of oncogenic mutations, such as Phosphatase and tensin homologue (PTEN) loss or Nucleophosminanaplastic lymphoma kinase (NPM/ALK) $[28,29]$. Amplification at 9p24.1, where PD-L1 resides, has been associated with PD-L1 up-regulation in squamous cell oral carcinoma [30] and non-small cell lung cancer [31]. The activation of the PI3K pathway in response to PTEN loss in both breast cancers [32] and glioblastomas [28] induces PD-L1 expression. Moreover, microRNA-200 (miR-200), a cell-autonomous suppressor of the epithelial mesenchymal transition (EMT) and metastasis, targets PD-L1 [33].

The data obtained in the present study demonstrated that in vivo education could induce surface PD-L1 expression on ovarian cancer cells. After excluding the role of T and B cells in PD-L1 expression through up-regulation using nude mice, we focused on the infiltration of TAMs. TAMs are a major source of inflammatory cytokines in the tumour microenvironment, among which TNF- $\alpha$, IL-10, IL-1, IL-6, IL-8, IL-12p40 and GM-CSF are abundant in the cancer microenvironment. Considering the importance of TAMs in promoting tumour progression, we investigated its effect on the PD-L1expression in tumour cells. These results not only reveal that PD-L1 expression could be increased by TAM-derived IFN- $\gamma$, TNF- $\alpha$, IL-10 and IL6 , but we also observed that the intensity of membranous PD-L1 was positively correlated with high TAM infiltration, strongly suggesting that the inducible surface-expression of PDL1 on tumour cells was correlated with TAMs in vivo and in vitro.

Based on PD-L1 protein blot assays, inducible membranous PD-L1 expression reflects increasing amounts of total protein expression, but not a shift in the proportion of surface versus intracellular protein, and the TAM-mediated up-regulation of PD-L1 expression in cells occurs through post-transcriptional mechanisms. Subsequently, we assessed the effects of IFN- $\gamma$ and TNF- $\alpha$-associated pathways on the expression of PD-L1 in SKOV3 cells. Over time, although ERK1/2 and PI3K activation was immediately increased as early as $15 \mathrm{~min}$ after treatment with IFN- $\gamma$ or TNF- $\alpha$, these molecules played different roles in the regulation of PD-L1 expression. The expression of PD-L1 on SKOV3 was induced through IFN- $\gamma$ via the PI3K pathway, and TNF- $\alpha$ induced the surface expression of PD-L1 on SKOV3 though the ERK1/2 pathway. However, gene amplification was unlikely to account for PD-L1 up- 
regulation mediated through TAMs in ovarian cancer in which PD-L1 copy number changes were not detected using real-time PCR.

As a consequence, the forced expression of PD-L1 on the surface of SKOV3 cells induced by TAMs suggests that CTL cells were more sensitive to surface-PD-1-mediated cell apoptosis. Furthermore, the detection of PD-L1 in cytoplasm of SKOV3 cells suggested an unanticipated function different from membranous PD-L1. According to Clark et al., tumour cell-intrinsic PD-L1 promotes mammalian target of rapamycin complex 1 (MTORC1) signalling in mouse melanoma and ovarian cancer, inhibits autophagy and sensitizes some tumours to clinically available pharmacological autophagy inhibitors and confers resistance to mammalian target of rapamycin (MTOR) inhibitors [34]. Here, the knockdown of PD-L1 expression using siRNA results in cancer cell growth and migration inhibition, as demonstrated using CCK-8 and transwell assays. Indeed, these results provide evidence that intracellular PD-L1 exerts a pro-carcinogenic effect, and the elevated surface expression of PD-L1 is essential for the induction of PD- $1^{+} \mathrm{T}$ cell death.

PD-1 is expressed following the activation of naive T cells, and its expression decreases when the antigen is cleared. Blocking PD-1 can reinvigorate exhausted CD8 T cells and improve the control of cancer [35]. PD-1 pathway blockade also resulted in transcriptional rewiring and the reengagement of effector circuitry in the exhausted $C D 8^{+} \mathrm{T}$ cells epigenetic landscape [36]. Here, tumour-bearing mice displayed an obvious increase of PD- $1^{+} \mathrm{CD} 8^{+} \mathrm{T}$ cell in tumour and spleen tissues. Interestingly, PD-L1 mAb or PD-1 mAb injection not only inhibited tumour growth but also showed potential to decrease PD $-1^{+} \mathrm{CD} 8^{+} \mathrm{T}$ cells. Available preliminary data alluded to PD-L1 expression in tumours as a potential predictive biomarker of responses to anti-PD-1/PD-L1 drugs, suggesting that PD-1 expression in immune infiltrated cells might be associated with clinical benefit.

\section{Conclusion}

In summary, the results of the present study indicated that cancer cells express surface PD-L1 in the presence of TAMs. This result demonstrated a new mechanism by which ovarian carcinoma escapes from immune surveillance and might have therapeutic potential for immune approaches targeting ovarian cancer. Therefore, in selecting patients for PDL1-targeted therapy in ovarian cancer, it may be necessary to assess not only the PD-L1 status on surface but also in the cytoplasm of the affected cells to predict whether the case will be sensitive to the therapy or not. These findings provide important new insights into the significance of cancer-stromal cell interactions in influencing the outcomes of cancer immunotherapy [37].

\section{Acknowledgements}

The authors would like to thank Dr. Abbey Turner (University of Pittsburgh) for reviewing this manuscript. This work was financially supported through grants from the Project of National Natural Science Foundation of China (81101556) and Suzhou Social Development Project (SYS201605 and SYS201338) and the Key Laboratory of Medicine of Jiangsu Province (XK201635) and the Medical Youth of Jiangsu Province (QNRC2016708).

\section{Disclosure Statement}

The authors have no disclosures to report.

\section{References}

1 Pierredon S, Ribaux P, Tille JC, Petignat P, Cohen M: Comparative secretome of ovarian serous carcinoma: Gelsolin in the spotlight. Oncol Lett 2017;13:4965-4973. 


\section{Cellular Physiology Cell Physiol Biochem 2017;43:1893-1906 \begin{tabular}{ll|l} 
DOI: 10.1159/000484109 & $\begin{array}{l}\text { O 2017 The Author(s). Published by S. Karger AG, Basel } \\
\text { www.karger.com/cpb }\end{array}$ \\
and Biochemistry Published online: October 20, 201
\end{tabular}}

2 Bast RC, Jr., Hennessy B, Mills GB: The biology of ovarian cancer: new opportunities for translation. Nat Rev Cancer 2009;9:415-428.

-3 Honeychurch J, Cheadle EJ, Dovedi SJ, Illidge TM: Immuno-regulatory antibodies for the treatment of cancer. Expert Opin Biol Ther 2015;15:787-801.

4 Suzuki S, Ishida T, Yoshikawa K, Ueda R: Current status of immunotherapy. Jpn J Clin Oncol 2016;46:191203.

5 Cacan E: Epigenetic-mediated immune suppression of positive co-stimulatory molecules in chemoresistant ovarian cancer cells. Cell Biol Int 2017;41:328-339.

6 Carreno BM, Collins M: The B7 family of ligands and its receptors: new pathways for costimulation and inhibition of immune responses. Annu Rev Immunol 2002;20:29-53.

7 Brahmer JR, Pardoll DM: Immune checkpoint inhibitors: making immunotherapy a reality for the treatment of lung cancer. Cancer Immunol Res 2013;1:85-91.

-8 Philips GK, Atkins M: Therapeutic uses of anti-PD-1 and anti-PD-L1 antibodies. Int Immunol 2015;27:3946.

9 Xia B, Herbst RS: Immune checkpoint therapy for non-small-cell lung cancer: an update. Immunotherapy 2016;8:279-298.

10 Sheppard KA, Fitz LJ, Lee JM, Benander C, George JA, Wooters J, Qiu Y, Jussif JM, Carter LL, Wood CR, Chaudhary D: PD-1 inhibits T-cell receptor induced phosphorylation of the ZAP70/CD3zeta signalosome and downstream signaling to PKCtheta. FEBS Lett 2004;574:37-41.

-11 Yokosuka T, Takamatsu M, Kobayashi-Imanishi W, Hashimoto-Tane A, Azuma M, Saito T: Programmed cell death 1 forms negative costimulatory microclusters that directly inhibit $\mathrm{T}$ cell receptor signaling by recruiting phosphatase SHP2. J Exp Med 2012;209:1201-1217.

12 Patsoukis N, Sari D, Boussiotis VA: PD-1 inhibits T cell proliferation by upregulating p27 and p15 and suppressing Cdc25A. Cell Cycle 2012;11:4305-4309.

13 Chatterjee J, Dai W, Aziz NHA, Teo PY, Wahba J, Phelps DL, Maine CJ, Whilding LM, Dina R, Trevisan G, Flower KJ, George AJT, Ghaem-Maghami S: Clinical Use of Programmed Cell Death-1 and Its Ligand Expression as Discriminatory and Predictive Markers in Ovarian Cancer. Clin Cancer Res 2017;23:34533460 .

14 Webb JR, Milne K, Kroeger DR, Nelson BH: PD-L1 expression is associated with tumor-infiltrating T cells and favorable prognosis in high-grade serous ovarian cancer. Gynecol Oncol 2016;141:293-302.

15 Yang M, Liu P, Wang K, Glorieux C, Hu Y, Wen S, Jiang W, Huang P: Chemotherapy induces tumor immune evasion by upregulation of programmed cell death ligand 1 expression in bone marrow stromal cells. Mol Oncol 2017;11:358-372.

16 Takada K, Okamoto T, Shoji F, Shimokawa M, Akamine T, Takamori S, Katsura M, Suzuki Y, Fujishita T, Toyokawa G, Morodomi Y, Okano S, Oda Y, Maehara Y: Clinical Significance of PD-L1 Protein Expression in Surgically Resected Primary Lung Adenocarcinoma. J Thorac Oncol 2016;11:1879-1890.

17 Inman BA, Sebo TJ, Frigola X, Dong H, Bergstralh EJ, Frank I, Fradet Y, Lacombe L, Kwon ED: PD-L1 (B7H1) expression by urothelial carcinoma of the bladder and BCG-induced granulomata: associations with localized stage progression. Cancer 2007;109:1499-1505.

-18 McLaughlin J, Han G, Schalper KA, Carvajal-Hausdorf D, Pelekanou V, Rehman J, Velcheti V, Herbst R, LoRusso P, Rimm DL: Quantitative Assessment of the Heterogeneity of PD-L1 Expression in Non-Small-Cell Lung Cancer. JAMA Oncol 2016;2:46-54.

19 Shi SJ, Wang LJ, Wang GD, Guo ZY, Wei M, Meng YL, Yang AG, Wen WH: B7-H1 expression is associated with poor prognosis in colorectal carcinoma and regulates the proliferation and invasion of HCT116 colorectal cancer cells. PLoS One 2013;8:e76012.

20 Chen J, Li G, Meng H, Fan Y, Song Y, Wang S, Zhu F, Guo C, Zhang L, Shi Y: Upregulation of B7-H1 expression is associated with macrophage infiltration in hepatocellular carcinomas. Cancer Immunol Immunother 2012;61:101-108.

21 Darb-Esfahani S, Kunze CA, Kulbe H, Sehouli J, Wienert S, Lindner J, Budczies J, Bockmayr M, Dietel M, Denkert C, Braicu I, Johrens K: Prognostic impact of programmed cell death-1 (PD-1) and PD-ligand 1 (PDL1) expression in cancer cells and tumor-infiltrating lymphocytes in ovarian high grade serous carcinoma. Oncotarget 2016;7:1486-1499. 


\section{Cellular Physiology Cell Physiol Biochem 2017;43:1893-1906 \begin{tabular}{l|l|l} 
DOI: 10.1159/000484109 & $\begin{array}{l}\text { O 2017 The Author(s). Published by S. Karger AG, Basel } \\
\text { www.karger.com/cpb }\end{array}$
\end{tabular} \\ Qu et al.: Expression of PD-L1 in Ovarian Cancer Cells}

22 Brahmer JR, Tykodi SS, Chow LQ Hwu WJ, Topalian SL, Hwu P, Drake CG, Camacho LH, Kauh J, Odunsi K, Pitot HC, Hamid O, Bhatia S, Martins R, Eaton K, Chen S, Salay TM, Alaparthy S, Grosso JF, Korman AJ, Parker SM, Agrawal S, Goldberg SM, Pardoll DM, Gupta A, Wigginton JM: Safety and activity of anti-PD-L1 antibody in patients with advanced cancer. N Engl J Med 2012;366:2455-2465.

-23 Brahmer J, Reckamp KL, Baas P, Crino L, Eberhardt WE, Poddubskaya E, Antonia S, Pluzanski A, Vokes EE, Holgado E, Waterhouse D, Ready N, Gainor J, Aren Frontera O, Havel L, Steins M, Garassino MC, Aerts JG, Domine M, Paz-Ares L, Reck M, Baudelet C, Harbison CT, Lestini B, Spigel DR: Nivolumab versus Docetaxel in Advanced Squamous-Cell Non-Small-Cell Lung Cancer. N Engl J Med 2015;373:123-135.

24 Hodi FS, Chesney J, Pavlick AC, Robert C, Grossmann KF, McDermott DF, Linette GP, Meyer N, Giguere JK, Agarwala SS, Shaheen M, Ernstoff MS, Minor DR, Salama AK, Taylor MH, Ott PA, Horak C, Gagnier P, Jiang J, Wolchok JD, Postow MA: Combined nivolumab and ipilimumab versus ipilimumab alone in patients with advanced melanoma: 2-year overall survival outcomes in a multicentre, randomised, controlled, phase 2 trial. Lancet Oncol 2016;17:1558-1568.

25 Kuang DM, Zhao Q, Peng C, Xu J, Zhang JP, Wu C, Zheng L: Activated monocytes in peritumoral stroma of hepatocellular carcinoma foster immune privilege and disease progression through PD-L1. J Exp Med 2009;206:1327-1337.

26 Bloch 0, Crane CA, Kaur R, Safaee M, Rutkowski MJ, Parsa AT: Gliomas promote immunosuppression through induction of B7-H1 expression in tumor-associated macrophages. Clin Cancer Res 2013;19:31653175.

-27 Chen J, Feng Y, Lu L, Wang H, Dai L, Li Y, Zhang P: Interferon-gamma-induced PD-L1 surface expression on human oral squamous carcinoma via PKD2 signal pathway. Immunobiology 2012;217:385-393.

-28 Parsa AT, Waldron JS, Panner A, Crane CA, Parney IF, Barry JJ, Cachola KE, Murray JC, Tihan T, Jensen MC, Mischel PS, Stokoe D, Pieper RO: Loss of tumor suppressor PTEN function increases B7-H1 expression and immunoresistance in glioma. Nat Med 2007;13:84-88.

29 Marzec M, Zhang Q, Goradia A, Raghunath PN, Liu X, Paessler M, Wang HY, Wysocka M, Cheng M, Ruggeri BA, Wasik MA: Oncogenic kinase NPM/ALK induces through STAT3 expression of immunosuppressive protein CD274 (PD-L1, B7-H1). Proc Natl Acad Sci U S A 2008;105:20852-20857.

-30 Straub M, Drecoll E, Pfarr N, Weichert W, Langer R, Hapfelmeier A, Gotz C, Wolff KD, Kolk A, Specht K: CD274/PD-L1 gene amplification and PD-L1 protein expression are common events in squamous cell carcinoma of the oral cavity. Oncotarget 2016;7:12024-12034.

- 31 Ikeda S, Okamoto T, Okano S, Umemoto Y, Tagawa T, Morodomi Y, Kohno M, Shimamatsu S, Kitahara H, Suzuki Y, Fujishita T, Maehara Y: PD-L1 Is Upregulated by Simultaneous Amplification of the PD-L1 and JAK2 Genes in Non-Small Cell Lung Cancer. J Thorac Oncol 2016;11:62-71.

-32 Mittendorf EA, Philips AV, Meric-Bernstam F, Qiao N, Wu Y, Harrington S, Su X, Wang Y, Gonzalez-Angulo AM, Akcakanat A, Chawla A, Curran M, Hwu P, Sharma P, Litton JK, Molldrem JJ, Alatrash G: PD-L1 expression in triple-negative breast cancer. Cancer Immunol Res 2014;2:361-370.

-33 Chen L, Gibbons DL, Goswami S, Cortez MA, Ahn YH, Byers LA, Zhang X, Yi X, Dwyer D, Lin W, Diao L, Wang J, Roybal J, Patel M, Ungewiss C, Peng D, Antonia S, Mediavilla-Varela M, Robertson G, Suraokar M, Welsh JW, Erez B, Wistuba, II, Chen L, Peng D, Wang S, Ullrich SE, Heymach JV, Kurie JM, Qin FX: Metastasis is regulated via microRNA-200/ZEB1 axis control of tumour cell PD-L1 expression and intratumoral immunosuppression. Nat Commun 2014;5:5241.

34 Clark CA, Gupta HB, Curiel TJ: Tumor cell-intrinsic CD274/PD-L1: A novel metabolic balancing act with clinical potential. Autophagy 2017;13:987-988.

35 Shayan G, Srivastava R, Li J, Schmitt N, Kane LP, Ferris RL: Adaptive resistance to anti-PD1 therapy by Tim-3 upregulation is mediated by the PI3K-Akt pathway in head and neck cancer. Oncoimmunology 2017;6:e1261779.

-36 Pauken KE, Sammons MA, Odorizzi PM, Manne S, Godec J, Khan O, Drake AM, Chen Z, Sen DR, Kurachi M, Barnitz RA, Bartman C, Bengsch B, Huang AC, Schenkel JM, Vahedi G, Haining WN, Berger SL, Wherry EJ: Epigenetic stability of exhausted T cells limits durability of reinvigoration by PD-1 blockade. Science 2016;354:1160-1165.

-37 Adams SF, Benencia F: Immunotherapy for ovarian cancer: what are the targets of the future? Future Oncol 2015;11:1293-1296. 